\title{
Synthesis of $\mathrm{MnO}_{2}$ on Activated Carbon and its Potential Application in the Adsorption of $\mathrm{As}(\mathrm{V})$ and $\mathrm{Pb}(\mathrm{II})$ in Aqueous Solutions
}

\author{
Roberto Contreras-Bustos, ${ }^{1}$ E. Manríquez-Reza, ${ }^{1}$ Jaime Jiménez-Becerril, ${ }^{2, *}$ \\ Melania Jiménez-Reyes ${ }^{2}$ and Bibiana Cercado-Quezada ${ }^{1}$
}

\author{
${ }^{1}$ Centro de Investigación y Desarrollo Tecnológico en Electroquímica S. C., Parque Tecnológico Querétaro, Sanfandila, \\ Pedro Escobedo, C. P. 76703, Querétaro. México. \\ ${ }^{2}$ Departamento de Química, Instituto Nacional de Investigaciones Nucleares, Apartado Postal 18-1027. C. P. 11801, \\ Distrito Federal, México. \\ * Corresponding author: E-mail: jaime.jimenez@inin.gob.mx \\ Telephone: + (55) 53297200
}

Received: 08-02-2017

\begin{abstract}
The conditions for the synthesis of a material with $\mathrm{MnO}_{2}(\mathrm{OMD})$ on activated carbon (AC) were studied. These conditions were: reaction time, temperature, stirring speed, concentrations of $\mathrm{AC}, \mathrm{H}_{2} \mathrm{SO}_{4}$, and $\mathrm{O}_{3}$ in solution, and particle size. Agglomerates on AC were observed by means of scanning electron microscopy (SEM) and microanalysis by energy dispersive spectroscopy (EDS) and revealed the presence of OMD deposited on the surface. The activation energy and the factor of frequency for the reaction were determined as $E_{\mathrm{a}}=1.2 \mathrm{kcal} / \mathrm{mol}$ and $A=2.2$. The value of $E_{\mathrm{a}}$ indicates that the precipitation of OMD on the AC was controlled by mass transfer in aqueous solution and the order of reaction was zero. The adsorption capacities of AC were $q=14 \mathrm{mg} \mathrm{Pb}(\mathrm{II}) / \mathrm{g} \mathrm{AC}$ and $q=9.1 \mathrm{mg} \mathrm{As}(\mathrm{V}) / \mathrm{g} \mathrm{AC}$. Whereas, for the OMD/AC obtained in the following conditions: [AC] 1 or $2 \mathrm{~g} / \mathrm{L}$, particle size of $\mathrm{AC}$ of $+0.59 \mathrm{~mm},\left[\mathrm{H}_{2} \mathrm{SO}_{4}\right] 1$ or $2 \mathrm{~mol} / \mathrm{L}, 25^{\circ} \mathrm{C}$, stirring speed $600 \mathrm{rpm}$, and $\left[\mathrm{O}_{3}\right] 1.35 \mathrm{~mol} / \mathrm{L}$, the adsorption capacities were $q=90.5 \mathrm{mg} \mathrm{Pb}(\mathrm{II}) / \mathrm{g}$ OMD/AC and $25.4 \mathrm{mg}$ $\mathrm{As}(\mathrm{V}) / \mathrm{g} \mathrm{OMD} / \mathrm{AC}$. Therefore, the fixing of OMD on the surface of the AC greatly improved the removal of both $\mathrm{Pb}(\mathrm{II})$ and $\mathrm{As}(\mathrm{V})$ from aqueous solutions.
\end{abstract}

Keywords: $\mathrm{MnO}_{2}$, Activated carbon, Lead, Arsenic, Adsorption

\section{Introduction}

Studies on absorbent materials for natural and anthropogenic contaminant ions, in both surface water and groundwater, remain of interest. Arsenic and lead ions have notable deleterious effects on human health. In Mexico, their presence has been detected in aquifers, especially in the north of the country. ${ }^{1}$ They cause various diseases including skin diseases, bone diseases and diseases in other vital organs. Moreover, they can lead to death when high-dose exposure is continuous. Thus, it is important to find efficient alternatives for the removal of these ions from water and to reduce the risks to human health.

Arsenic is present in the atmosphere, soil, rocks, natural water and organisms. Most environmental problems related to arsenic contamination are due to mobilization under natural conditions. For human beings, arsenic has an important impact in the form of mining, burning fossil fuels and use of arsenic-containing pesticides, herbicides and livestock feed. ${ }^{2}$ The presence of arsenic in water usually indicates nearby mines or metallurgical industries in operation or agricultural areas where materials with arsenic are used. ${ }^{3}$ The average levels of arsenic in groundwater are between 0.001 and $0.002 \mathrm{mg} / \mathrm{L}$; however, in areas with volcanic rocks and sulfide ore deposits, these levels are $>3 \mathrm{mg} / \mathrm{L}$. The World Health Organization (WHO) established that the arsenic in water for human consumption should not exceed $0.01 \mathrm{mg} / \mathrm{L} .{ }^{4}$ This is a provisional value given the uncertainty of the risks associated with a lower concentration of arsenic; in 1984, the WHO had set limit 
value of $0.05 \mathrm{mg} / \mathrm{L}$. The U.S. Environmental Protection Agency (EPA) indicates a maximum permissible limit concentration of arsenic of $0.01 \mathrm{mg} / \mathrm{L}$ for drinking water. ${ }^{5}$ The Mexican official standard is a maximum permissible limit concentration of $0.025 \mathrm{mg} / \mathrm{L} .^{6}$

Lead is present in the environment, including in the air, dust, soil and water. This element and its compounds are widely used for batteries, pigments, ammunitions, weldings, pipes, coated cables and bearings. Other sources of contamination are mining and smelting waste, petrol and paintings. ${ }^{7}$ The maximum permissible limit concentration of lead in drinking water established by the WHO for water is $0.01 \mathrm{mg} / \mathrm{L}$. Per the U.S. EPA, the limit is $0.015 \mathrm{mg} / \mathrm{L}$, though it is also $0.01 \mathrm{mg} / \mathrm{L}$ according to the Mexican official standard. ${ }^{4-6}$

There are several technologies for the treatment of contaminated water with arsenic and lead ions such as coagulation-filtration, chemical precipitation, ion exchange and lime softening, among others. ${ }^{7-15}$ In recent years, research has been conducted on low-cost and easily obtainable materials that may be useful for absorbing heavy metals. Among these materials are: activated charcoal, zeolites, chitosan, clays, biocarbon, and sand. ${ }^{16-19}$ To increase the adsorption capacity of these natural adsorbents materials, changes to their surfaces have been proposed. For lead removal, several possibilities have been tested, including: manganese dioxide onto zeolites, sand or resins, cellulose, carbon nanotubes, pretreated clinoptilolite, and graphene. ${ }^{20-25}$ Regarding arsenic removal, the deposition of $\mathrm{MnO}_{2}$ (OMD) onto polystyrene resins, zeolites and MCM- 41 has been proposed. ${ }^{10,11,26-30}$

Oxidation of manganese ions by ozone in an aqueous solution has been widely studied, and it is a feasible alternative for the production of OMD.$^{31}$ Ozone is one of the strongest oxidants and offers the advantage of not introducing unwanted specimen into the system; therefore, its use guarantees the purity of the product obtained. OMD obtained via this method has better characteristics than if it was produced via other methods. Moreover, this type of OMD exhibits good behavior for ion exchange. ${ }^{32-34}$ Preferentially, OMD exchanges with other ions in the order $\mathrm{Pb}(\mathrm{II})>\mathrm{Zn}(\mathrm{II})>\mathrm{Cd}(\mathrm{II})>\mathrm{Tl}(\mathrm{I}) .{ }^{35}$

Activated carbon (AC) is a low-cost adsorbent that, depending on the conditions of the adsorbate, can be used in a wide $\mathrm{pH}$ range. Its adsorption capacity stems not only from its surface area but also its physicochemical nature, i.e. properties obtained during the activation process. ${ }^{36-38}$ Manganese dioxide obtained by specific conditions of ozonation (OMD) has better adsorption capabilities than if it was obtained by electrolytic or chemical methods. The size of the OMD obtained by direct precipitation is relatively small. An interesting option is the use of a supporting material such as AC to obtain a larger material useful in traditional adsorption columns. The synthesis of OMD consumes electricity for the for- mation of ozone; however, with the use of alternate energy sources (i.e., solar), costs could be mitigated. Manganese sulfate can be obtained during the acid leaching of manganese ore, whose oxidation with ozone can be directly applied in the presence of $\mathrm{AC}$. The cost of obtaining OMD from manganese ore is comparable to that of obtaining it by the electrolytic method. In addition, $\mathrm{OMD} / \mathrm{AC}$ provides the features for adsorption of $\mathrm{Pb}$ (II) or $\mathrm{As}(\mathrm{V})$; furthermore, the reversibility of adsorption has been proved for cadmium(II) and zinc(II) with an acid solution at $\mathrm{pH} 1-2 .{ }^{35}$

The present investigation proposes the synthesis of an adsorbent material, which consists of OMD supported by AC to examine whether its physical and chemical characteristics are suitable for the adsorption columns used in water purification. The specific aims of this research are: 1) to establish the best conditions for the synthesis of $\mathrm{OMD} / \mathrm{AC}, 2$ ) to characterize the material, and 3) to determine the adsorption capacity of the material for $\mathrm{Pb}(\mathrm{II})$ and $\mathrm{As}(\mathrm{V})$ ions.

\section{Experimental}

\section{1. Synthesis of $\mathrm{MnO}_{2} / \mathrm{AC}$}

For the synthesis of the OMD, $\mathrm{MnSO}_{4}$ (Karal S. A. de C. V., reagent grade) and $\mathrm{H}_{2} \mathrm{SO}_{4}$ (Baker, reagent grade) were used. Granular AC type CAGR $8 \times 30$ (Clarimex), certified by the National Science Foundation and previously characterized was used..$^{39}$ The AC is of lignite origin, is activated by vapor steam, has an average pore diameter of $3.5 \mathrm{~nm}$ and has a surface area of $664 \mathrm{~m}^{2} / \mathrm{g}$. The determinations using the inductively coupled plasma (ICP-OES) spectrometry (Perkin Elmer, Optima 3300 DV) gave the following data: Al: $256 \mathrm{mg} / \mathrm{kg}, \mathrm{Si}: 143$ $\mathrm{mg} / \mathrm{kg}$, Na: $1085 \mathrm{mg} / \mathrm{kg}, \mathrm{K}: 300 \mathrm{mg} / \mathrm{kg}$, Ca: $872 \mathrm{mg} / \mathrm{kg}$, Sr: $756 \mathrm{mg} / \mathrm{kg}$ and V: $14 \mathrm{mg} / \mathrm{kg}$.

OMD synthesis was performed via the oxidation by ozonation of $\mathrm{Mn}$ (II) in aqueous solution. A solution of $1 \mathrm{~g} / \mathrm{L}$ of $\mathrm{MnSO}_{4}$ and $1 \mathrm{~mol} / \mathrm{L} \mathrm{H}_{2} \mathrm{SO}_{4}$ was prepared with deionized water and was deposited in a glass reactor with $2 \mathrm{~g}$ of AC. The system was stirred to $600 \mathrm{rpm}$ for $2 \mathrm{~h}$, and the temperature was controlled at $25^{\circ} \mathrm{C}$. A gaseous mixture of $\mathrm{O}_{2} / \mathrm{O}_{3}$, produced in an ozone generator (PCI Ozone \& Control Systems, mod. GL-1) supplied with oxygen was introduced into the reactor. Samples were taken at 0 , $30,60,90$ and $120 \mathrm{~min}$ of reaction. The samples were filtered and the solid was washed with $100 \mathrm{~mL}$ of deionized water. These samples were identified as OMD/AC. Finally, the samples were stored in a desiccator. Liquid samples were analyzed by ICP-OES.

The base conditions for the synthesis were: temperature, $25^{\circ} \mathrm{C}$; stirring, $600 \mathrm{rpm}$; concentration of $\mathrm{AC}, 2 \mathrm{~g} / \mathrm{L}$; $\left[\mathrm{H}_{2} \mathrm{SO}_{4}\right], 1 \mathrm{~mol} / \mathrm{L}$; $\left[\mathrm{O}_{3}\right]$ in solution, $1.32 \mathrm{~mol} / \mathrm{L}$; and particle size of $\mathrm{AC},+0.59 \mathrm{~mm}$. Each parameter was independently varied in order to find out the best adsorption capa- 
city of the material for $\mathrm{Pb}(\mathrm{II})$ and $\mathrm{As}(\mathrm{V})$ ions. The temperature ranged from 25 to $70{ }^{\circ} \mathrm{C}$; the concentration of $\mathrm{AC}$ from 0.5 to $5 \mathrm{~g} / \mathrm{L}$; the ozone concentration in solution from 0.35 to $1.65 \mathrm{~mol} / \mathrm{L}$; the concentration of $\mathrm{H}_{2} \mathrm{SO}_{4}$ from 1 to $3 \mathrm{~mol} / \mathrm{L}$; the stirring speed from 200 to $800 \mathrm{rpm}$; and the particle size from $\mathrm{AC}$ of +0.59 to $+1.6 \mathrm{~mm}$.

The resulting solid material was characterized using scanning electron microscopy (SEM) and microanalysis by Energy Dispersive Spectroscopy (EDS) (Jeol, mod. JSM35CFLV) to corroborate the presence of manganese deposits on the surface of the $\mathrm{AC}$ and to identify other elements in the samples.

\section{2. Adsorption of Lead and Arsenic}

The solutions used for the experiment were one of lead and one of arsenic, each with a concentration of $1 \mathrm{~g}$ of the element per liter. They were prepared with $\mathrm{Pb}\left(\mathrm{NO}_{3}\right)_{2}$ (Baker, reactive grade) and $\mathrm{Na}_{2} \mathrm{HAsO}_{4} \cdot 7 \mathrm{H}_{2} \mathrm{O}$ (Mallinckrodt Chemical Works, reagent grade) in deionized water. These solutions were stored in polyethylene containers. The stock solutions were diluted up to a concentration of $100 \mathrm{mg} / \mathrm{L}$ for the adsorption experiments. $0.1 \mathrm{~g}$ of OMD/AC prepared in specific conditions was put in contact with $100 \mathrm{~mL}$ of these solutions. For lead, the adsorption experiments were carried out at $\mathrm{pH}=4.7$ to avoid the precipitation of lead as hydroxide. According to the chemical species diagram at $\mathrm{pH}=4.7$ lead is present only as $\mathrm{Pb}(\mathrm{II}) .{ }^{40}$ Arsenic experiments were done at $\mathrm{pH} 8.8$, when $\mathrm{As}(\mathrm{V})$ can be found as the anionic species $30 \%$ $\left(\mathrm{H}_{2} \mathrm{AsO}_{4}\right)^{-}$. Contact was done in an isothermal bath with stirring at $300 \mathrm{rpm}$ at $25^{\circ} \mathrm{C}$ for $24 \mathrm{~h}$.

After the contact the solutions were filtered and a nitric acid solution added to maintain the $\mathrm{pH}<2$, the samples were stored in polyethylene bottles. Lead was then present as $\mathrm{Pb}(\mathrm{II})$ and $\mathrm{As}(\mathrm{V})$ was ca. $70 \%$ as $\mathrm{H}_{3} \mathrm{AsO}_{4}$ and ca. $30 \% \mathrm{H}_{2} \mathrm{AsO}_{2}{ }^{4-}$ all of which are water soluble. ${ }^{40}$ These samples were analyzed for $\mathrm{Pb}(\mathrm{II})$ or $\mathrm{As}(\mathrm{V})$ using ICPOES. The OMD/AC was flushed with $100 \mathrm{~mL}$ of deionized water, dried at temperatures up to $35^{\circ} \mathrm{C}$ for $12 \mathrm{~h}$ and stored in a desiccator with silica gel.

To determine the influence of each individual condition on the synthesis of OMD/AC, the adsorption capacity of the material for $\mathrm{Pb}(\mathrm{II})$ and $\mathrm{As}(\mathrm{V})$ was tested using the material obtained under different stirring speed, ozone concentration, acidity, AC concentration, temperatures, and $\mathrm{AC}$ particle sizes.

The equation used for the calculation of the adsorption capacity was:

$$
q=\frac{\left(C_{i}-C_{f}\right) * V}{m}
$$

where $q$ is the adsorption capacity (mg ion/g adsorbent), $m$ is the mass of the adsorbent $(\mathrm{g}), C_{\mathrm{i}}$ is the initial concentration of ions in solution $(\mathrm{mg} / \mathrm{L}), C_{\mathrm{f}}$ is the final concentration of ions in solution $(\mathrm{mg} / \mathrm{L})$ and $V$ is the volume of the solution (L). ${ }^{41}$ The adsorption capacity of AC for $\mathrm{Pb}(\mathrm{II})$ and $\mathrm{As}(\mathrm{V})$ was measured as well.

\section{Results and Discussion}

\section{1. OMD/AC Synthesis}

\section{1. 1. Stirring Speed}

The values of $\mathrm{Mn}$ (II) when remaining in solution for the same amount of time are very similar (Table 1); this means that the parameter does not significantly alter the oxidation rate reaction. It can be deduced that the masstransfer phenomenon in that range of stirring speed is not important. A slight increase of $\mathrm{Mn}(\mathrm{II})$ deposition was observed, however, at a stirring speed of $800 \mathrm{rpm}$ at $120 \mathrm{mi}-$ nutes of reaction. $\mathrm{Mn}$ (II) probably spreads in the AC by means of electrostatic attraction with the electrically charged sites of the surface, and then, when ions are already deposited, oxidation occurs to form OMD.

\section{1. 2. Ozone Concentration}

Table 1 shows the influence of the concentration of ozone on the oxidation rate reaction of $\mathrm{Mn}$ (II) in the presence of AC. The oxidation rate increases in relation to the concentration of ozone in solution. The best conditions for attaining the lowest concentration of $\mathrm{Mn}(\mathrm{II})$ in solution are $1.35 \mathrm{~mol} / \mathrm{L}$ and $120 \mathrm{~min}$ of reaction.

With $t>90$ min of ozonation and a concentration of $\mathrm{O}_{3}$ of $1.65 \mathrm{~mol} / \mathrm{L}$, a re-dissolution of manganese ions was

Table 1. Manganese concentration $(\mathrm{mg} / \mathrm{L}$, in italics) remaining in solution, with respect to stirring speed (rpm), ozone concentration (mol/L) and reaction time (min).

\begin{tabular}{ccccccrrr}
\hline $\mathbf{t}$ & \multicolumn{4}{c}{ Stirring (rpm) } & & \multicolumn{3}{c}{$\left[\mathbf{O}_{\mathbf{3}}\right](\mathbf{m o l} / \mathbf{L})$} \\
$(\mathbf{m i n})$ & $\mathbf{2 0 0}$ & $\mathbf{4 0 0}$ & $\mathbf{6 0 0}$ & $\mathbf{8 0 0}$ & $\mathbf{0 . 3 5}$ & $\mathbf{1 . 3 2}$ & $\mathbf{1 . 3 5}$ & $\mathbf{1 . 6 5}$ \\
\hline 0 & 1000 & 1000 & 1000 & 1000 & 1000 & 1000 & 1000 & 1000 \\
30 & 920 & 826 & 834 & 816 & 890 & 834 & 790 & 680 \\
60 & 770 & 705 & 711 & 642 & 780 & 670 & 590 & 360 \\
90 & 608 & 550 & 508 & 410 & 670 & 508 & 388 & 38 \\
120 & 423 & 380 & 377 & 184 & 565 & 340 & 180 & 299 \\
\hline
\end{tabular}


observed due to the oxidation of the ions $\mathrm{Mn}(\mathrm{IV})$ up to $\mathrm{Mn}$ (VII), revealed by the characteristic violet color. In accordance with the Pourbaix diagram at the experimental $\mathrm{pH}, \mathrm{Mn}$ (II) can be oxidized to $\mathrm{MnO}_{2}$ and subsequently to $\mathrm{MnO}_{4}{ }^{-42}$ The calculation of the order of reaction was performed with the following equation:

$$
\log \left(-r_{A}\right)=\log k+n \log C_{A}
$$

where $r_{A}$ expresses the variation of the concentration of a species $(\mathrm{Mn}(\mathrm{II}))$ with respect to time, $C_{A}$ is the concentration of ozone, $k$ is the rate constant and $n$ ) is the order of reaction.

The graphics (not included) corresponding to 30, 60 and $90 \mathrm{~min}$ of stirring and ozone concentrations of 0.35 to $1.35 \mathrm{~mol} / \mathrm{L}$ have slopes $\approx 0.5$; this is considered a zero-order reaction. The value of $\log \left(-\mathrm{r}_{\mathrm{A}}\right)$ tended to be higher, indicating a change in slope, only in the case of $90 \mathrm{~min}$ and $1.35 \mathrm{~mol} / \mathrm{L}$ ozone. For the lowest concentrations of ozone in solution the mass-transfer phenomena have more influence in the process than the chemical reaction itself during oxidation of $\mathrm{Mn}$ (II). However, as the concentration of dissociated ozone increases, the chemical reaction becomes more important. ${ }^{43}$

\section{1. 3. Sulfuric-acid Concentration}

The oxidation rate reaction of $\mathrm{Mn}(\mathrm{II})$ decreases with the increase in sulfuric-acid concentration (Table 2). For the range of acidity used, the best condition was $1 \mathrm{~mol} / \mathrm{L}$ $\mathrm{H}_{2} \mathrm{SO}_{4}$. Moreover, the start-up time for reaction increases when the acid concentration increases. The low rate of oxidation with high concentrations of $\mathrm{H}_{2} \mathrm{SO}_{4}$ may be due to a competition between protons and $\mathrm{Mn}$ (II) ions for the active sites of AC. Another explanation is that the low rate of oxidation is due to the high viscosity observed with a high concentration of acid.

\section{1. 4. AC Concentration}

As can be seen in Table 2, the values corresponding to the change of $\mathrm{Mn}$ (II) for the oxidation reaction without AC have tendency very similar to that of the tests carried out with the presence of AC. Rodríguez-Santillan et al. mention that the $\mathrm{AC}$ favors the decomposition of $\mathrm{O}_{3}$ in solution even at low $\mathrm{pH} ;{ }^{44}$ however, in the conditions of the present work, this was not observed.

According to the calculations done in accordance with Equation 2, the oxidation reaction is of zero-order with respect to this variable. This means that, in the interval of the AC used, this parameter does not have a significant influence on the rate of oxidation of $\mathrm{Mn}$ (II) by ozone.

\section{1. 5. AC Particle Size}

The rate reaction is quite similar for the three particle sizes, namely $0.59,1.19$ and $1.6 \mathrm{~mm}$ (Table 3 ). Thus, it can be deduced that this variable does not influence the process of oxidation of $\mathrm{Mn}(\mathrm{II})$.

\section{1. 6. Temperature}

Increasing temperature to $70{ }^{\circ} \mathrm{C}$ and reaction times to greater than 60 min favors oxidation; for lower temperatures, there was no noticeable difference (Table

Table 2. Manganese concentration (mg/L, in italics) remaining in solution, with respect to initial sulfuric-acid concentration (mol/L), quantity of activated carbon $(\mathrm{g})$ and reaction time $(\mathrm{min})$.

\begin{tabular}{|c|c|c|c|c|c|c|c|c|c|}
\hline \multirow{2}{*}{$\begin{array}{c}\mathrm{t} \\
(\mathrm{min})\end{array}$} & \multicolumn{3}{|c|}{$\left[\mathrm{H}_{2} \mathrm{SO}_{4}\right](\mathrm{mol} / \mathrm{L})$} & \multicolumn{6}{|c|}{$\mathrm{AC}(\mathrm{g})$} \\
\hline & $\mathbf{1}$ & 2 & 3 & $\mathbf{0}$ & 0.5 & 1 & 2 & 3 & 5 \\
\hline 0 & 1000 & 1000 & 1000 & 1000 & 1000 & 1000 & 1000 & 1000 & 1000 \\
\hline 30 & 834 & 959 & 992 & 743 & 723 & 761 & 834 & 787 & 742 \\
\hline 60 & 711 & 852 & 925 & 592 & 549 & 629 & 711 & 651 & 657 \\
\hline 90 & 508 & 654 & 848 & 439 & 351 & 392 & 508 & 489 & 448 \\
\hline 120 & 377 & 452 & 805 & 255 & 143 & 269 & 377 & 246 & 276 \\
\hline
\end{tabular}

Table 3. Manganese concentration ( $\mathrm{mg} / \mathrm{L}$, in italics) remaining in solution, with respect to the particle size of activated carbon (mm), temperature $\left({ }^{\circ} \mathrm{C}\right)$ and reaction time ( $\left.\mathrm{min}\right)$.

\begin{tabular}{|c|c|c|c|c|c|c|c|}
\hline \multirow{2}{*}{$\begin{array}{c}\mathbf{t} \\
(\mathbf{m i n})\end{array}$} & \multicolumn{3}{|c|}{ Particle size (mm) } & \multicolumn{4}{|c|}{ Temperature $\left({ }^{\circ} \mathbf{C}\right)$} \\
\hline & 0.59 & 1.19 & 1.6 & 25 & 40 & 60 & 70 \\
\hline 0 & 1000 & 1000 & 1000 & 1000 & 1000 & 1000 & 1000 \\
\hline 30 & 834 & 751 & 793 & 834 & 840 & 876 & 876 \\
\hline 60 & 711 & 589 & 618 & 711 & 666 & 643 & 647 \\
\hline 90 & 508 & 404 & 412 & 508 & 469 & 419 & 417 \\
\hline 120 & 377 & 242 & 251 & 377 & 251 & 221 & 60 \\
\hline
\end{tabular}


3). Similar observations have been reported previously. ${ }^{35}$

The $k$ values for temperatures of $25,40,60$, and $70{ }^{\circ} \mathrm{C}$ were calculated considering the slopes of the graphs of Figure 1A. These values were used to determine the activation energy by the Arrhenius linear equation:

$$
\ln k=\ln A-E_{\mathrm{a}} / R T
$$

where $k$ is the rate constant, $A$ is the factor of frequency, $E_{\mathrm{a}}$ is the activation energy $(\mathrm{kcal} / \mathrm{mol}), R$ is the universal constant of the gases, and $T$ is temperature $(\mathrm{K})$.

Figure 1B shows a graph in which the activation energy and the factor of frequency are the slope and the intercept of the line, respectively. These values are $E_{\mathrm{a}}=$ $1.2 \mathrm{kcal} / \mathrm{mol}$ and $A=2.2$. According to Peters and Bolton, $E_{\mathrm{a}}$ values under $4.7 \mathrm{kcal} / \mathrm{mol}$ and occasionally under $2.3 \mathrm{kcal} / \mathrm{mol}$ correspond to mechanisms controlled by mass-transfer in an aqueous solution; ${ }^{45}$ therefore, deposition of $\mathrm{MnO}_{2}$ on $\mathrm{AC}$ can be considered as such. Thus, temperature does not influence the process of $\mathrm{MnO}_{2}$ precipitation.

\section{2. Characterization by SEM}

Figure 2 shows typical images obtained by SEM. In the micrograph taken to the scale of $150 \times$ and $100 \mu \mathrm{m}$ (a), fine particles were observed on the AC. Yet, in the micrograph taken to the scale of $2000 \times$ and $10 \mu \mathrm{m}$ (b), agglomerates of OMD were deposited on the surface of the AC. The EDS (c) revealed the presence of manganese and silicon, which were located on the AC surface.

When low ozone concentrations were used for synthesis, the images showed less deposits of manganese on the AC than on samples synthesized with high concen-

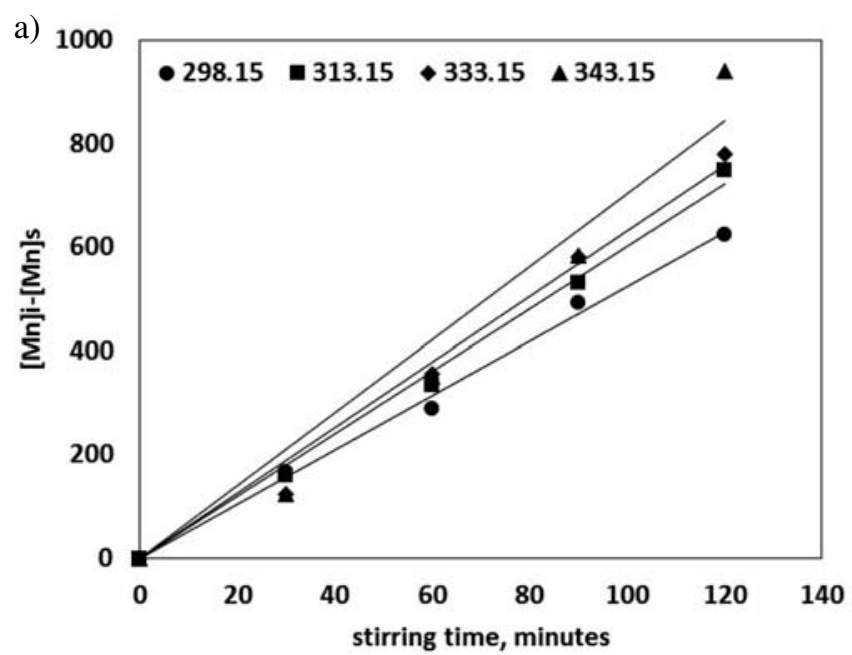

trations of ozone; thus, the increase of ozone can be said to favors precipitation.

\section{3. Adsorption of $\mathrm{Pb}(\mathrm{II})$ in $\mathrm{OMD} / \mathrm{AC}$}

Table 4 shows the influence of different conditions on the synthesis of OMD/AC in terms of the composite's adsorption capacity for lead. This adsorption capacity increases with the stirring speed, probably due stirring speed's creation of more homogeneous deposits of OMD. However, the OMD/AC formed at $800 \mathrm{rpm}$ does not present the best features for removing $\mathrm{Pb}(\mathrm{II})$, because the dissemination processes do not favor the solid-liquid interface or because the contact time between the particles of OMD and AC was reduced. Moreover, this condition of synthesis could also create fractures of AC particles; hence, the OMD deposited on them may become detached.

The adsorption capacity of lead in the OMD/AC increased when the concentration of ozone used in the synthesis of the material was changed from 0.35 to 1.32 $\mathrm{mol} / \mathrm{L}$ (Table 4); however, with higher concentrations, this adsorption capacity decreased. This can be explained by a partial re-dissolution of manganese as $\mathrm{MnO}_{4}^{-}$during synthesis, and resulting decrease of manganese as an oxide on the surface of the AC, which is the chemical species that allows for efficient adsorption.

Table 4 also shows the influence of sulfuric-acid concentration. When the concentration of the acid reaches $2 \mathrm{M}$, the formation of $\gamma-\mathrm{MnO}_{2}$ is promoted, thereby increasing adsorption capacity. A higher concentration of sulfuric acid ( $3 \mathrm{~mol} / \mathrm{L}$ ) favors the formation of $\mathrm{Mn}(\mathrm{III})$, an intermediate species between $\mathrm{Mn}(\mathrm{II})$ and $\mathrm{MnO}_{2} \cdot{ }^{35} \mathrm{In}$ addition, in this case, the decrease of manganese as an oxide on the surface of the $\mathrm{AC}$ reduces the lead adsorption capacity of the material.

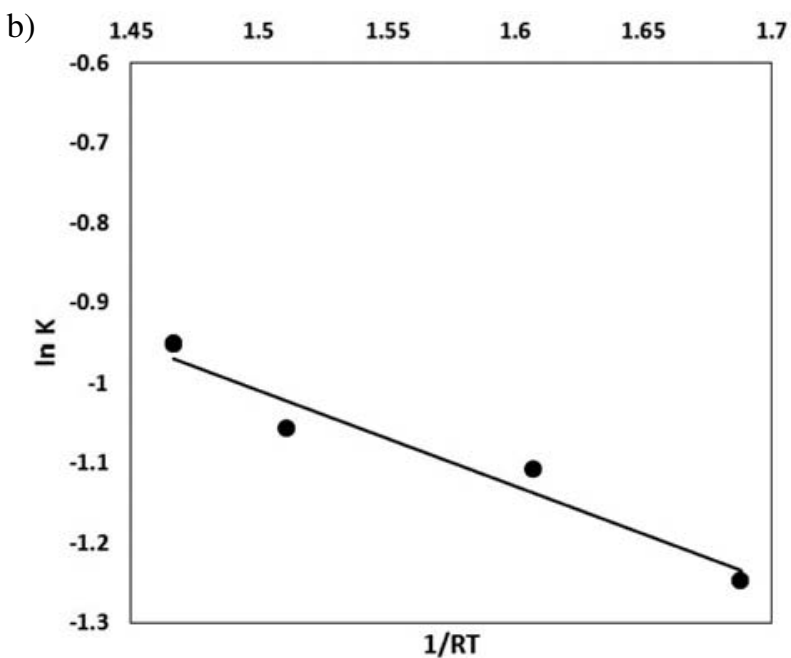

Figure 1. a: Initial manganese $(\mathrm{mg} / \mathrm{L})$ minus manganese remaining in solution as a function of stirring time. The slopes are: $5.24,6.02,6.33$, and 7.04 for $298.15,313.15,333.15$, and $343.15 \mathrm{~K}$, respectively. b: Estimation of activation energy by means of the Arrhenius equation. Ln K = $-1.2 *(1 / \mathrm{RT})+0.797(\mathrm{R} 2=0.94)$ 
The adsorption capacity of $\mathrm{Pb}(\mathrm{II})$ by $\mathrm{OMD} / \mathrm{AC}$ decreases when the concentration of AC used in the synthesis of the material increases (Table 4), for the amount of OMD present in the adsorbent material is proportionally smaller.

The best adsorption capacity with respect to the temperature of the formation of the OMD/AC was 82.7 $\mathrm{mg} \mathrm{Pb}(\mathrm{II}) / \mathrm{g}$ in the material prepared at $40{ }^{\circ} \mathrm{C}$. The adsorption capacity of the material is reduced at higher temperatures during synthesis. Umetsu et al. reported a similar behavior; they observed that OMD does not present adsorption for a synthesis at $70{ }^{\circ} \mathrm{C} .{ }^{46}$ Although there are significant deposits of OMD in the synthesized material at that temperature, the results indicate that the main factor responsible for the removal of $\mathrm{Pb}(\mathrm{II})$ is $\mathrm{AC}$.

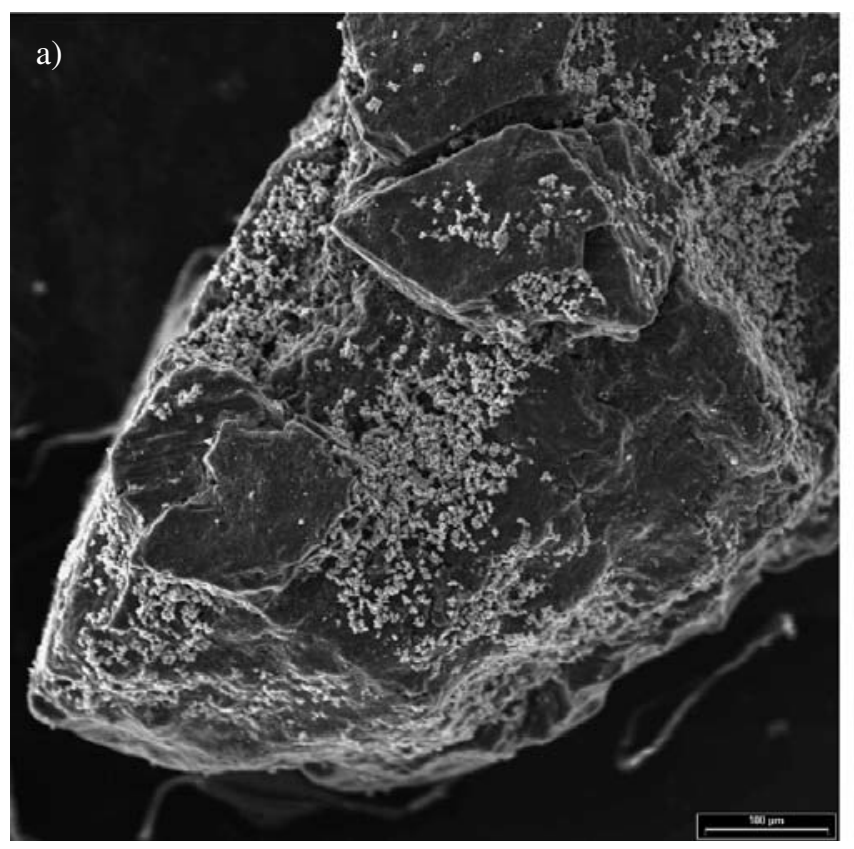

Regarding particle size, the best adsorption capacity (85.8 $\mathrm{mg} \mathrm{Pb}(\mathrm{II}) / \mathrm{g}$ OMD/AC) was obtained using the synthesized material with the largest AC particle, because it presents more deposits of OMD on the surface. In the intermediate-sized synthesized material with $\mathrm{AC}$, the removal of $\mathrm{Pb}$ (II) was reduced because of small amount OMD deposits, which was observed in the micrographs for particles sizes of 0.59 and $1.6 \mathrm{~mm}$. Finally, when using the smallest $\mathrm{AC}$ particles, the $\mathrm{Pb}(\mathrm{II})$ removal was also high (71.7 $\mathrm{mg} \mathrm{Pb}(\mathrm{II}) / \mathrm{g} \mathrm{OMD} / \mathrm{AC}$ ); the presence of few OMD deposits, the adsorption capacity increased if the si$\mathrm{ze}$ of the AC was reduced.

The conditions of synthesis of OMD/AC with the maximum adsorption capacity of $\mathrm{Pb}(\mathrm{II})$ are: $2 \mathrm{~mol} / \mathrm{L}$ of sulfuric acid, temperature at $25^{\circ} \mathrm{C}$, stirring at $600 \mathrm{rpm}, \mathrm{AC}$ par-

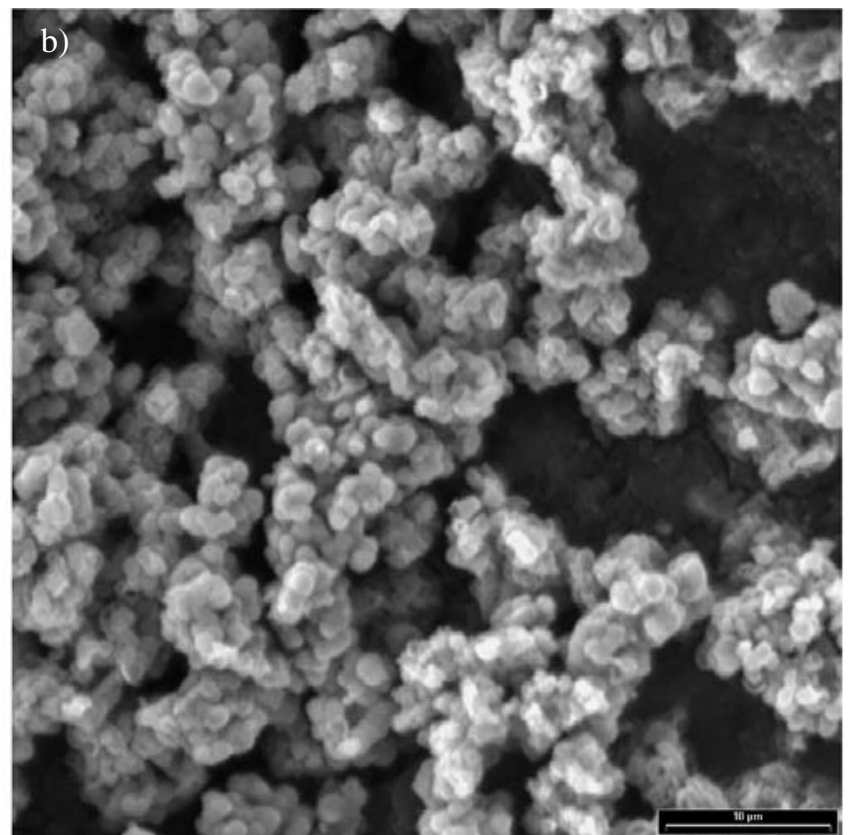

c)

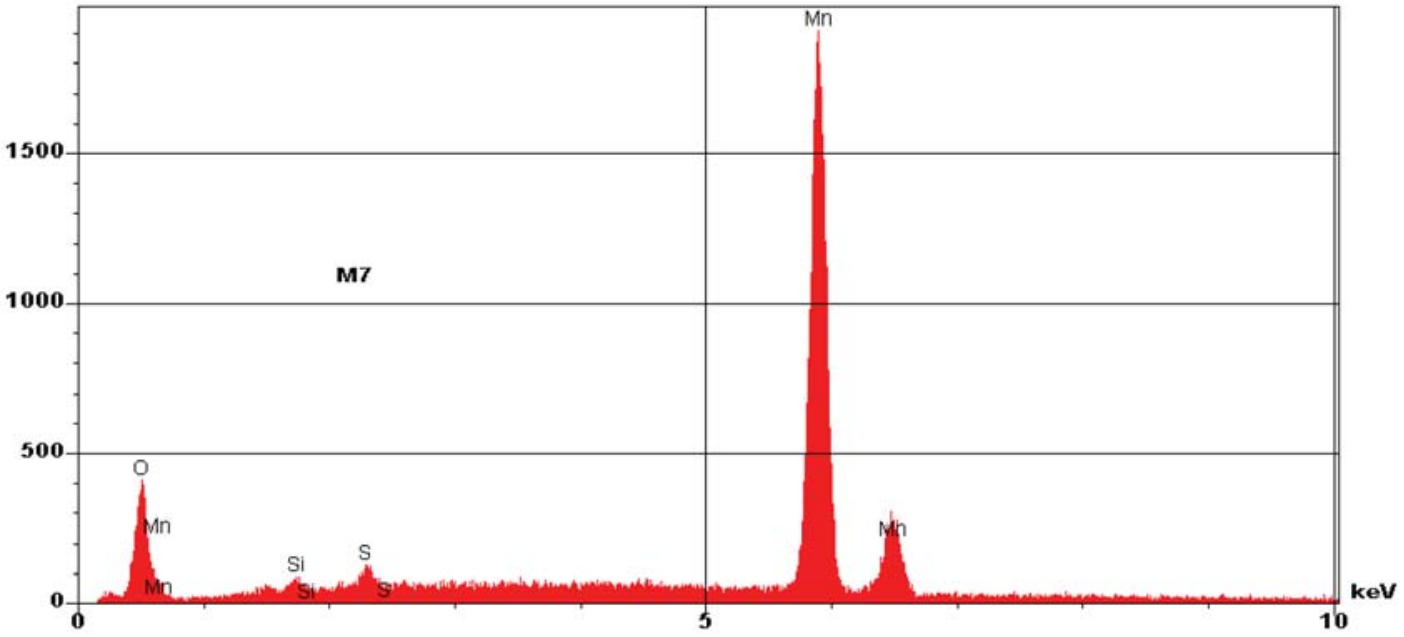

Figure 2. Typical micrographies of the synthetized materials. (a) 150x, (b) 2000x, (c) EDS obtained in micrography. 
Table 4. Adsorption capacities of $\mathrm{OMD} / \mathrm{AC}$ for $\mathrm{Pb}(\mathrm{II})$ and $\mathrm{As}(\mathrm{V})$ with respect to different synthesis parameters for OMD/AC. Initial concentrations $=100 \mathrm{mg} / \mathrm{L}$. Without OMD, $q_{0}=14.0 \mathrm{mg} \mathrm{Pb}(\mathrm{II}) / \mathrm{g} \mathrm{AC}$ and $q_{0}=9.1$ $\mathrm{mg} \mathrm{As}(\mathrm{V}) / \mathrm{g}$ AC.

\begin{tabular}{|c|c|c|c|}
\hline $\begin{array}{l}\text { Synthesis parameters } \\
\text { for OMD/AC }\end{array}$ & Condition & $\begin{array}{c}q(\mathrm{mg} \mathrm{Pb}(\mathrm{II}) / \mathrm{g} \\
\text { OMD/AC) }\end{array}$ & $\begin{array}{c}q(\mathrm{mg} \mathrm{As}(\mathrm{V}) / \mathrm{g} \\
\text { OMD/AC) }\end{array}$ \\
\hline \multirow{4}{*}{ Temperature $\left({ }^{\circ} \mathrm{C}\right)$} & 25 & 71.7 & 4.3 \\
\hline & 40 & 82.7 & 19.0 \\
\hline & 60 & 70.7 & 18.8 \\
\hline & 70 & 71.0 & 8.0 \\
\hline \multirow{4}{*}{ Stirring (rpm) } & 200 & 54.6 & 17.3 \\
\hline & 400 & 60.9 & 18.5 \\
\hline & 600 & 71.7 & 4.3 \\
\hline & 800 & 39.3 & 4.7 \\
\hline \multirow{4}{*}[\mathrm{O}_{3}]{$(\mathrm{mol} / \mathrm{L})$} & 0.35 & 40.0 & 5.6 \\
\hline & 1.32 & 71.7 & 4.3 \\
\hline & 1.35 & 56.6 & 1.0 \\
\hline & 1.65 & 76.8 & 4.5 \\
\hline \multirow{5}{*}[\mathrm{AC}]{$(\mathrm{g} / \mathrm{L})$} & 0.5 & 84.6 & 17.6 \\
\hline & 1.0 & 81.4 & 25.1 \\
\hline & 2.0 & 72.0 & 4.3 \\
\hline & 3.0 & 20.3 & 1.8 \\
\hline & 5.0 & 44.0 & 7.3 \\
\hline \multirow{3}{*}[\mathrm{H}_{2}\mathrm{SO}_{4}]{$(\mathrm{mol} / \mathrm{L})$} & 1.0 & 71.7 & 4.3 \\
\hline & 2.0 & 90.6 & 16.5 \\
\hline & 3.0 & 34.7 & 19.5 \\
\hline \multirow{3}{*}{ Particle size of AC (mm) } & 0.59 & 71.7 & 4.3 \\
\hline & 1.19 & 49.5 & 19.7 \\
\hline & 1.60 & 85.8 & 10.1 \\
\hline
\end{tabular}

ticle size at $+0.59 \mathrm{~mm},\left[\mathrm{O}_{3}\right] 1.35 \mathrm{~mol} / \mathrm{L}$, and $[\mathrm{AC}] 2 \mathrm{~g} / \mathrm{L}$. The adsorption-capacity value in these conditions is 90.5 $\mathrm{mg} \mathrm{Pb}(\mathrm{II}) / \mathrm{g} \mathrm{OMD} / \mathrm{AC}$; for $\mathrm{AC}$, however, it is $14 \mathrm{mg} \mathrm{Pb}(\mathrm{II}) / \mathrm{g}$ AC. Therefore, the fixing of $\mathrm{MnO}_{2}$ on the surface of the $\mathrm{AC}$ greatly improves the removal of ions $\mathrm{Pb}(\mathrm{II})$ of aqueous solutions.

\section{4. Adsorption of $\mathrm{As}(\mathrm{V})$ in $\mathrm{OMD} / \mathrm{AC}$}

The results of the experiments carried out to determine the adsorption capacity of $\mathrm{As}(\mathrm{V})$ on the material in each of the conditions of synthesis was calculated in the same way as described for lead, following Equation 1 and determining the influence of each individual parameter. The values obtained are shown in Table 4 .

At the experimental $\mathrm{pH}(8.8), \mathrm{As}(\mathrm{V})$ can be found as an anionic species $\mathrm{H}_{2} \mathrm{AsO}_{4}{ }^{2-} \cdot{ }^{40}$ Even if the OMD is considered a cation exchanger, the use of this material to remove $\mathrm{As}(\mathrm{V})$ has been reported in the literature. ${ }^{47-49}$

Table 4 shows that the adsorption capacity was better with a slow stirring speed during synthesis (200 and $400 \mathrm{rpm}$ ); the highest value obtained was for $400 \mathrm{rpm}$ (18.5 mg As(V)/g OMD/AC). The increased stirring speed resulted in a drastic decrease in the adsorption capacity because of fewer deposits of manganese oxide, which is responsible for adsorption.
The ozone concentration used for the synthesis of $\mathrm{OMD} / \mathrm{AC}$ does not have a significant influence on the adsorption capacity for arsenic ions. The maximum adsorption capacity is less than $6 \mathrm{mg} \mathrm{As}(\mathrm{V}) / \mathrm{g} \mathrm{OMD} / \mathrm{AC}$ for a concentration of $\mathrm{O}_{3}=1.65 \mathrm{~mol} / \mathrm{L}$. This behavior is different from that observed with the adsorption of $\mathrm{Pb}$ (II) for the same parameter because the mechanism of ion exchange of the OMD is different for cations and anions.

The adsorption capacity of $\mathrm{As}(\mathrm{V})$ in $\mathrm{OMD} / \mathrm{AC}$ depends on $\mathrm{H}_{2} \mathrm{SO}_{4}$ concentration; it increased when that concentration increased from 1 to $3 \mathrm{M}$. The best adsorption capacity was $19.5 \mathrm{mg} \mathrm{As}(\mathrm{V}) / \mathrm{g} \mathrm{OMD} / \mathrm{AC}$ for $3 \mathrm{~mol} / \mathrm{L}$ of $\mathrm{H}_{2} \mathrm{SO}_{4}$. The increase of the anion exchange of the OMD is given by the presence of sulfate ions on the surface, which allowed for a greater exchange of anions. However, the variation of the adsorption capacity between 2 and 3 $\mathrm{mol} / \mathrm{L}$ did not produce noticeable changes. The amount of OMD deposited on the AC decreased when the concentration of the acid increased; therefore, the adsorption of $\mathrm{As}(\mathrm{V})$ also decreased.

An adsorption capacity of $25.1 \mathrm{mg} A \mathrm{As}(\mathrm{V}) / \mathrm{g}$ $\mathrm{OMD} / \mathrm{AC}$ was obtained when the concentration of $\mathrm{AC}$ was $1 \mathrm{~g} / \mathrm{L}$; with higher concentrations, smaller values were obtained. This behavior is similar to that observed for $\mathrm{Pb}(\mathrm{II})$, and similarly related to the amount of OMD pre- 
sent in the adsorbent material, which is proportionally smaller.

With respect to the temperature of the synthesis of $\mathrm{OMD} / \mathrm{AC}$, the tendency is the same for the $\mathrm{As}(\mathrm{V})$ as for the $\mathrm{Pb}$ (II). At low synthesis temperatures the adsorption capacity was higher showing the best results at $40^{\circ} \mathrm{C}$, although it remained virtually constant up to $60{ }^{\circ} \mathrm{C}$, with 19.0 and $18.5 \mathrm{mg} \mathrm{As}(\mathrm{V}) / \mathrm{g} \mathrm{OMD} / \mathrm{AC}$, respectively. At $70^{\circ} \mathrm{C}$ a significant decrease in the adsorption capacity was observed. The reduction of the ion-exchange capacity of OMD/AC meant that the capacity for retention of the material decreased when more deposits of manganese were present in the adsorbent material.

The adsorption of As(V) with respect to particle size displayed the opposite behavior as the adsorption of $\mathrm{Pb}(\mathrm{II})$. In this case, with the smallest particle size, the adsorption capacity was the lowest. The sample used for this experiment probably had few OMD deposits, so the main adsorbent was AC. For other particle size, OMD deposits were confirmed; however, no high adsorption capacity was observed. The highest adsorption capacity was 19.7 $\mathrm{mg} \mathrm{As}(\mathrm{V}) / \mathrm{g}$, for a particle size of $\mathrm{AC}=+1.19 \mathrm{~mm}$. The removal of $\mathrm{As}(\mathrm{V})$ does not present a clear tendency with regard to the particle size used for the synthesis of $\mathrm{OMD} / \mathrm{AC}$ in the present work.

The best adsorption capacity obtained was $25.4 \mathrm{mg}$ $\mathrm{As}(\mathrm{V}) / \mathrm{g} \mathrm{OMD} / \mathrm{AC}$ with a material prepared as follows: AC concentration $1 \mathrm{~g} / \mathrm{L}$, temperature at $25{ }^{\circ} \mathrm{C}$, stirring speed at $600 \mathrm{rpm}, \mathrm{AC}$ particle size at $+0.59 \mathrm{~mm},\left[\mathrm{O}_{3}\right] 1.35$ $\mathrm{mol} / \mathrm{L}$, and $\left[\mathrm{H}_{2} \mathrm{SO}_{4}\right] 1 \mathrm{~mol} / \mathrm{L}$. The adsorption capacity of $\mathrm{As}(\mathrm{V})$ in $\mathrm{AC}$ is $9.1 \mathrm{mg} \mathrm{As}(\mathrm{V}) / \mathrm{g} \mathrm{AC}$; therefore, it can be seen that the presence of OMD greatly improves the absorption of As(V).

The mechanism of removing the $\mathrm{As}(\mathrm{V})$ in anionic form from water by the OMD/AC is complicated. The first stage is probably the formation of complexes on the surface of the AC, which is followed by ion exchange. The adsorption of anions has been related to reactions of complex formations on protonated sites or the presence of electrophilic sites. The $\mathrm{As}(\mathrm{V})$ is quite basic, suggesting that its adsorption in $\mathrm{AC}$ has a close relationship with the concentration of functional strong acid groups.

\section{5. Comparison of the Adsorption Data for $\mathrm{Pb}(\mathrm{II})$ and $\mathrm{As}(\mathrm{V})$}

One published review focused on adsorbents for the removal of arsenic, cadmium, and lead from contaminated waters. ${ }^{50}$ Table 5 shows a comparison of the present work's data and some data from the literature for the same kind of adsorbent material. The adsorption capacity of OMD/CA is similar to that of $\mathrm{Al}_{2} \mathrm{O}_{3}$-pillared layered $\mathrm{MnO}_{2}$ and $\mathrm{Al}$ pillared montmorillonite $(\mathrm{A}, \mathrm{B})$ and better than that of other materials. Regarding the adsorption capacity of $\mathrm{OMD} / \mathrm{CA}$ for $\mathrm{As}(\mathrm{V})$, the result obtained is not too low; though there are other materials with higher values of $q$.

\section{Conclusions}

The conditions for the synthesis of a material with $\mathrm{MnO}_{2}$ (OMD) on activated carbon (AC) were studied. It can be deduced that mass-transfer phenomena in the range of the stirring speed (200-800 rpm) are not important. The oxidation rate increases according to the concentration of ozone in solution and the best conditions for attaining the lowest concentration of $\mathrm{Mn}(\mathrm{II})$ in solution which results in more deposits of manganese dioxide are $1.35 \mathrm{~mol} / \mathrm{L}$ and $120 \mathrm{~min}$ of reaction. The rate of reaction of $\mathrm{Mn}(\mathrm{II})$ oxidation decreases with increased in sulfuric-acid concentration. Neither the concentration nor the particle size of $\mathrm{AC}$ influences the process of oxidation of $\mathrm{Mn}$ (II). Increasing temperature to $70{ }^{\circ} \mathrm{C}$ and a reaction time to greater than $60 \mathrm{~min}$ favors oxidation; for lower temperatures, oxidation is not significantly different.

For all experimental conditions agglomerates on AC were observed by means of SEM and EDS and the presence of manganese dioxide deposited on the surface of the $\mathrm{AC}$ was identified. The activation energy and the factor of frequency for the reaction were determined as $E_{\mathrm{a}}=1.2$ $\mathrm{kcal} / \mathrm{mol}$ and $A=2.2$, respectively. The value of $E_{\mathrm{a}}$ indicates that the precipitation of manganese dioxide in the $\mathrm{AC}$ is controlled by mass transfer in aqueous solution. The order of this reaction is zero.

The best conditions for the synthesis of OMD/AC to ensure maximum adsorption capacity for $\mathrm{Pb}$ (II) and

Table 5. Comparison of the adsorption capacities $(q)$ of the materials in the present work and those of previously studied materials.

\begin{tabular}{|c|c|c|c|c|c|}
\hline Material & $\begin{array}{c}q \\
(\mathbf{m g ~ P b}(\mathrm{II}) / \mathrm{g})\end{array}$ & Ref. & Material & $\begin{array}{c}q \\
(\mathrm{mg} \mathrm{As}(\mathrm{V}) / \mathrm{g})\end{array}$ & Ref. \\
\hline$\overline{\mathrm{CA}}$ & 14 & This & $\mathrm{CA}$ & 9.1 & This \\
\hline $\mathrm{OMD} / \mathrm{AC}$ & 90.5 & work & $\mathrm{OMD} / \mathrm{AC}$ & 25.4 & work \\
\hline$\delta-\mathrm{MnO}_{2}$ & 27.81 & 51 & Calcite/ $\alpha-\mathrm{MnO}_{2}$ & 10.36 & 47 \\
\hline $\mathrm{Al}_{2} \mathrm{O}_{3}$-pillared layered $\mathrm{MnO}_{2}$ & 80.22 & & Calcite/goethite/ $\alpha-\mathrm{MnO}_{2}$ & 41.94 & \\
\hline Montmorillonite-K10 & $95-97$ & 52 & $\mathrm{MnO}_{2}$ nanowires/diatomite & 108.2 & 48 \\
\hline \multicolumn{6}{|l|}{ Al-pillared clay } \\
\hline$\alpha-\mathrm{MnO}_{2}$ & $99.8 \%$ & 53 & Functionalized-nanoporous $\mathrm{C} / \mathrm{MnO}_{2}$ & 9.43 & 49 \\
\hline $\mathrm{MnO}_{2} /$ carbon nanotubes & 6.7 & 54 & & & \\
\hline Silica/4-amino-2-mercaptopyridine & $2.45 \mu \mathrm{mol} / \mathrm{g}$ & 55 & & & \\
\hline
\end{tabular}


As(V) were established. These values are $90.5 \mathrm{mg}$ $\mathrm{Pb}$ (II)/g OMD/AC and 25.4 mg As(V)/g OMD/AC. When only $\mathrm{AC}$ is used, these values are: $14 \mathrm{mg} \mathrm{Pb}(\mathrm{II}) / \mathrm{g} \mathrm{AC}$ and $9.1 \mathrm{mg} \mathrm{As}(\mathrm{V}) / \mathrm{g}$ AC. Therefore, the fixing of $\mathrm{MnO}_{2}$ on the surface of the $\mathrm{AC}$ greatly improves the removal of $\mathrm{Pb}$ (II) and $\mathrm{As}(\mathrm{V})$ from aqueous solutions.

\section{Acknowledgement}

The authors would like to recognize the financing provided by CONACYT-Mexico in the form of Project No. 59989 and the scholarship awarded to E. ManríquezReza.

\section{References}

1. M. Fuentes, Arsénico en las Incrustaciones en las Redes de Distribución de Agua Potable en el Norte de México y su Desprendimiento, Agua Latinoamérica, Marzo/abril, 15, 2005. http://www.bvsde.paho.org/bvsAIDIS/PuertoRico29 /fuentes.pdf (assessed: January 27, 2017)

2. WHO, Air Quality Guidelines - Second Edition. Chapter 6.7 Lead, World Health Organization, Regional Office for Europe, Copenhagen, Denmark, 2001.

http://www.euro.who.int/_data/assets/pdf_file/ 0020/123077/ AQG2ndEd_6_7Lead.pdf (assessed: January 27, 2017)

3. F. N. Kemmer and J. McCallion, Manual del agua. Su naturaleza, tratamiento y aplicaciones. Tomo I, II. 1ra. ed. McGraw - Hill. México, 1989. ISBN 9684225156

4. WHO. Guidelines for drinking-water quality [electronic resource]: incorporating first addendum. Vol. 1, Recommendations. $-3^{\text {rd }}$ ed., World Health Organization, ISBN 924 154696 4, NML classification: WA 675, 2006.

http://www.who.int/water_sanitation_health/dwq/ gdwq 0506.pdf (assessed: January 27, 2017).

5. US-EPA, National Primary Drinking Water Regulations EPA 816-F-03-016 U.S. Environmental Protection Agency, 2003. https://www.epa.gov/ground-water-and-drinking-water/table-regulated-drinking-water-contaminants (assessed: January 27, 2017)

6. Secretaria de Salud, Norma Oficial Mexicana NOM-127SSA1-1994, Salud ambiental. Agua para uso y consumo humano. Límites permisibles de calidad y tratamientos a que debe someterse el agua para su potabilización, 2000. http://www.gob.mx/cms/uploads/attachment/file/110534/ NOM_127_SSA1_1994.pdf (assessed: January 27, 2017)

7. J. R. Conner, Chemical fixation and solidification of hazardous wastes, Springer Netherlands, 1990. ISBN 978-0-44220511-9

8. P. C. Hayes, Process Selection in extractive metallurgy, Hayes Publishing Co. 1985. ISBN 0958919712

9. V. Lenoble, C. Laclautre, B. Serpaud, V. Deluchat and J. C. Bollinger, Sci. Total Environ., 2004 326(1-3), 197-207. http://dx.doi.org/10.1016/j.scitotenv.2003.12.012
10. V. Petkova, M. de L. Rivera, M. Piña, M. Avilés, and S. Pérez, Evaluación de diversos minerales para la remoción de arsénico de agua para consumo humano, Memorias técnicas. XI Congreso Nacional de Ingeniería Sanitaria y Ambiental. Zacatecas, 11997.

http://www.zeocat.es/docs/aguaarsenico.pdf (assessed: January 31 2017)

11. M. L. Rivera and M. Piña, Tratamiento de agua para remoción de arsénico mediante adsorción sobre zeolita natural acondicionada, 2005.

http://www.zeocat.es/docs/aguaarsenico2.pdf (assessed: January 27, 2017)

12. US EPA, Technologies and Costs for Removal of Arsenic from Drinking Water, EPA 815R00028, Prepared by Malcolm Pirnie, Inc. under contract $68 \mathrm{C} 60039$ for EPA ORD, December 2000.

https://nepis.epa.gov/Exe/ZyPDF.cgi/P1004WDI.PDF?Dockey=P1004WDI.PDF (assessed: January 27, 2017)

13. US-EPA, Arsenic Treatment Technologies for soil, waste and water, U.S. Environmental Protection Agency, EPA-542-R02-004, 2002.

https://www.epa.gov/sites/production/files/2015-04/documents/arsenic_report.pdf (assessed: January 31, 2017)

14. J. G. Parsons, M. L. Lopez, J. R. Peralta-Videa and J. L. Gardea-Torresdey, Microchem. J. 2009, 91, 100-106. http://dx.doi.org/10.1016/j.microc.2008.08.012

15. R. Contreras-Bustos, F. Espejel-Ayala, B. Cercado-Quezada, J. Jiménez-Becerril and M. Jiménez-Reyes, Pol. J. Chem. Technol. 2016, 18, 46-50. https://doi.org/10.1515/pjct-2016-0008

16. V. López-Ramón, C. Moreno-Castilla, J. Rivera-Utrilla and L.R. Radovic, Carbon 2002, 41, 2020-2022. http://dx.doi.org/10.1016/S0008-6223(03)00184-2

17. M. M. Rao, A. Ramesh, G. P. C. Rao and K. Seshaiah, J. Hazard. Mater. 2006, 129, 123-129.

http://dx.doi.org/10.1016/j.jhazmat.2005.08.018

18. L. Beesley and M. Marmiroli, Environ. Pollut. 2011, 159, 474-480. http://dx.doi.org/10.1016/j.envpol.2010.10.016

19. A. Bogusz, P. Oleszczuk and R. Dobrowolski, Bioresource Technol. 2015, 196, 540-549. http://dx.doi.org/10.1016/j.biortech.2015.08.006

20. D. Dong, L. Liu, X. Hua and Y. Lu, Microchem. J. 2007, 85, 270-275. http://dx.doi.org/10.1016/j.microc.2006.06.015

21. L. Dong, Z. Zhu, H. Ma, Y. Qiu and J. Zhao, J., Environ. Sci. 2010, 22, 225-229. http://dx.doi.org/10.1016/S1001-0742(09)60097-8

22. A. Günay, E. Arslankaya and I. Tosun, J. Hazard. Mater. 2007, 146, 362-371. http://dx.doi.org/10.1016/j.jhazmat.2006.12.034

23. Z. Song, F. Lian, Z. Yu, L. Zhu, B. Xing and W. Qiu, Chem. Eng. J. 2014, 242, 36-42. http://dx.doi.org/10.1016/j.cej.2013.12.061

24. Y. Ren, N. Yan, J. Feng, J. Ma, Q. Wen, N. Li and Q. Dong, Mater. Chem. Phys. 2012, 136, 538-544. http://dx.doi.org/10.1016/j.matchemphys.2012.07.023

25. S. Wang, B. Gao, Y. Li, A. Meuse, A. R. Zimmerman, L. Q. 
Ma, W. G. Harris and K. W. Migliaccio, Bioresour. Technol. 2015, 181, 13-17. http://dx.doi.org/10.1016/j.biortech.2015.01.044

26. L. M. Camacho, R. R. Parra and S. Deng, J. Hazard. Mater. 2011, 189, 286-293. http://dx.doi.org/10.1016/j.jhazmat.2011.02.035

27. R. Han, W. Zou, Z. Zhang, J. Shi and J. Yang, J. Hazard. Mater. 2006, 137, 384-395. http://dx.doi.org/10.1016/j.jhazmat.2006.02.021

28. S. Wang, W. Gong, X. Liu, Y. Yao, B. Gao and Q. Yue, Sep. Purif. Technol. 2017, 58, 17-23. http://dx.doi.org/10.1016/j.seppur.2007.07.006

29. Y. Wu, S. Yang, M. Zhang, A. Aierken and Y. Wu, Korean J. Chem. Eng. 2015, 32, 1667-1677. http://dx.doi.org/10.1007/s11814-014-0352-4

30. T. M. Albayati, G. M. Alwan and O. S. Mahdy, Korean J. Chem. Eng. 2017, 34, 259-265. http://dx.doi.org/10.1007/s11814-016-0231-2

31. N. Kijima, H. Yasuda, T. Sato and Y. Yoshimura, J. Solid State Chem. 2001, 159, 94-102. http://dx.doi.org/10.1006/jssc.2001.9136

32. R. Contreras and G. T. Lapidus, J. Colloid Interf. Sci. 1999, 213, 251-257. http://dx.doi.org/10.1006/jcis.1999.6114

33. C. Bigliocca, F. Girardi, J. Pauly,E. Sabbioni, S. Meloni and A. Provasoli, Anal. Chem. 1967, 39, 1634-1639. http://dx.doi.org/10.1021/ac50156a040

34. D. Glover, B. Schumm and A. Kozawa, Handbook of Manganese Dioxides Battery grade, International Battery Material Association (IBA Inc.), USA, 1989.

35. R. Contreras, Producción de dióxido de manganeso por ozonización y estudio de sus propiedades de intercambio iónico, Doctoral dissertation, Universidad Autónoma Metropolitana, campus Iztapalapa, Mexico, 1999.

http://tesiuami.izt.uam.mx/uam/aspuam/presentatesis. php?recno $=468 \&$ docs $=$ UAM0468.PDF

36. K. Schaeffer, Agua Latinoam. 2003, 3, 1-5. http://www.agualatinoamerica.com/docs/pdf/Intermedio.pdf (assessed: January 31, 2017)

37. R. Leyva, L. G. Velázquez, J. Mendoza and R. M. Guerrero, J. Mex. Chem. Soc. 2002, 46, 159-166. http://www.redalyc.org/pdf/475/47546214.pdf

38. A. J. Rubin and D. L. Mercer, In: Adsorption of Inorganics at Solid-Liquid Interfaces; Anderson, M. A.; Rubin, A. J. Ed.; Ann Arbor Science Publishers Inc.: 1981; p. 300.

39. H. Pérez, Modificación termoquímica y caracterización de un carbón activado lignítico, Barchelor dissertation, Universidad Veracruzana, 2006.

40. I. Puigdomenech, 2010. Program MEDUSA (Make Equilibrium Diagrams Using Sophisticated Algorithms). Royal
Institute of Technology, Inorganic Chemistry, Stockholm, swedenignasi@inorg.kth.se.

41. M. Al-Anber and Z. A. Al-Anber, Desalination 2008, 225, 70-81. http://dx.doi.org/10.1016/j.desal.2007.07.006

42. M. Pourbaix, Atlas d'équilibres électrochimiques, GauthierVillars, Paris, 1963.

43. C. Gottschalk, J. A. Libra and A. Saupe, Ozonation of water and waste water: A practical guide to understanding ozone and its applications, 2nd Ed., Wiley-VCH, Germany, 2010. ISBN: 978-3-527-31962-6

44. J. L. Rodríguez-Santillán, T. Poznyak and J. L. Mayorga, Efecto del pH y Carbón Activado Sobre la Descomposición de Ozono en Solución Acuosa, In: XXVII Encuentro Nacional de la AMIDIQ, 2006.

https://www.dropbox.com/s/57sdrecsy8amha3/2006.rar (assesed: January 31, 2017)

45. E. Peters and G. Bolton, Hydrometallurgy: Theory and Practice, Center for metallurgical and Process Engineering Department and Metallurgical Engineering, Chapter I, UBC. Vancouver, B. C. 1999. ISBN-13: 978-0444896568

46. T. Nishimura and Y. Umetsu, Shigen-to-Sozai 1992, 108, 373-377. https://doi.org/10.2473/shigentosozai.108.373

47. Y. Umetsu, T. Nishimura and R. C. Bustos, M. Tokuda, Shigen-to-Sozai 2000, 116, 999-1004. https://doi.org/10.2473/shigentosozai.116.999

48. J. S. Markovski, V. Dokić, M. Milosavljević, M. Mitrić, A. A. Perić-Grujić, A. A., A. E. Onjia, A. D. Marinković, Ultrason. Sonochem. 2014, 21, 790-801. https://doi.org/10.1016/j.ultsonch.2013.10.006

49. Y. Du, G. Zheng, J. Wang, L. Wang, J. Wu, H. Dai, Micropor. Mesopor. Mat. 2014, 200, 27-34. https://doi.org/10.1016/j.micromeso.2014.07.043

50. S. Pathan, N. Pandita, N. Kishore, Arabian J. Chem. 2016 Available online 31 December 2016. http://doi.org/10.1016/j.arabjc.2016.12.011.

51. S. K. R. Yadanaparthi, D. Graybill, R. von Wandruszka, J. Hazard. Mater. 2009, 171, 1-15. https://doi.org/10.1016/j.jhazmat.2009.05.103

52. H. Zhang, L. Gu, L. Zhang, S. Zheng, H. Wan, J. Sun, D. Zhu, Z. Xu, Appl. Surf. Sci. 2017, 406, 330-338.

53. D. Humelnicu, M. Ignat, M. Suchea, Acta Chim. Slov. 2015, 62, 947-957. https://doi.org/10.17344/acsi.2014.1825

54. S. T. El-Wakeel, R. S. El-Tawil, H. A. M. Abuzeid, A. E. Abdel-Ghany, A. M. Hashem, J. Taiwan Inst. Chem. Eng. 2017, 72, 95-103.

55. B. Yang, Q. Gong, L. Zhao, H. Sun, N. Ren, J. Qin, J. Xu, H. Yang, Desalination 2011, 278, 65-69. https://doi.org/10.1016/j.desal.2011.05.010 


\section{Povzetek}

Proučili smo pogoje za pripravo materialov z $\mathrm{MnO}_{2}(\mathrm{OMD})$ na aktivnem oglju (AC) in sicer reakcijski čas, temperaturo, hitrost mešanja, koncentracije $\mathrm{AC}, \mathrm{H}_{2} \mathrm{SO}_{4}$ in $\mathrm{O}_{3} \mathrm{v}$ raztopinah ter velikost delcev. Aglomerate na $\mathrm{AC}$ smo spremljali zvrstičnim elektronskim mikroskopom (SEM) in z mikroanalizo z energijsko disperzijsko spektroskopijo (EDS) potrdili prisotnost OMD depozitov na površini. Izračunali smo aktivacijsko energijo in frekvenčni faktor reakcije $E_{\mathrm{a}}=1.2$ $\mathrm{kcal} / \mathrm{mol}$ in $A=2.2$. Vrednost $E_{\mathrm{a}}$ kaže, da je nalaganje OMD na AC kontroliran z masnim prenosom v vodnih raztopinah, reakcija je ničtega reda.

Adsorpcijska kapaciteta AC je $q=14 \mathrm{mg} \mathrm{Pb}(\mathrm{II}) / \mathrm{g} \mathrm{AC}$ in $q=9.1 \mathrm{mg} \mathrm{As}(\mathrm{V}) / \mathrm{g}$ AC. Adsorpcijska kapaciteta na sistemu OMD/AC pri sledečih pogojih: [AC] 1 ali $2 \mathrm{~g} / \mathrm{L}$, velikost delcev $\mathrm{AC}+0.59 \mathrm{~mm},\left[\mathrm{H}_{2} \mathrm{SO}_{4}\right] 1$ ali $2 \mathrm{~mol} / \mathrm{L}, 25^{\circ} \mathrm{C}$, hitrost mešanja $600 \mathrm{rpm}$, in $\left[\mathrm{O}_{3}\right] 1.35 \mathrm{~mol} / \mathrm{L}$ je $q=90.5 \mathrm{mg} \mathrm{Pb}(\mathrm{II}) / \mathrm{g} \mathrm{OMD} / \mathrm{AC}$ in $25.4 \mathrm{mg} \mathrm{As}(\mathrm{V}) / \mathrm{g}$ OMD/AC. Vezava OMD na površino AC torej izredno izboljša odstranjevanje $\mathrm{Pb}(\mathrm{II})$ in $\mathrm{As}(\mathrm{V})$ iz vodnih raztopin. 